\title{
Changes in Tourists' Perception towards Visiting Bucegi Natural Park
}

\author{
Diana Elena DUMITRAŞ*, Ionel Mugurel JITEA*, Manuela Carmen SIMU \\ ${ }^{1}$ Department of Economic Sciences, University of Agricultural Sciences and Veterinary Medicine \\ Cluj-Napoca, Romania \\ *)Corresponding author, e-mail: ddumitras@usamvcluj.ro,mjitea@usamvcluj.ro
}

BulletinUASVM Horticulture 73(1) / 2016

Print ISSN 1843-5254, Electronic ISSN 1843-5394

DOI:10.15835/buasvmen-hort:11924

\begin{abstract}
The aim of the paper is to investigate if tourists' preferences toward visiting Bucegi Natural Park, Romania, have changed over time. The study seeks to elicit from the 'consumer', who is the tourist, useful information for management decisions. Tourists' preferences were analyzed using the choice experiments method within two studies. The park is presented as a set of several attributes with different states that tourists may be willing or not to experiences during their visit. The marginal willingness to pay is obtained for each attribute included in the choice set offered to respondents for evaluation. The set of attributes differ over the two studies to capture tourists' satisfaction over time in respond to management changes at the level of the park. The changes in behavior indicate that over the years people became more aware of the importance of sustainability of Bucegi Natural Park and also that the park administration has taken actions towards an optimal recreation use.
\end{abstract}

Keywords: choice experiments, management, natural park, tourism

\section{INTRODUCTION}

The process of revealing tourists' preferences for the characteristics and facilities of a natural park may be a difficult process unless it is not designed within a valid methodology. Choice experiments method was widely used to evaluate people preferences for several states of an environmental good (Louviere et al., 2000, Champ et al., 2003,). Hearne et al. (2002) analyzed preferences toward ecotourism development on Costa Rica by surveying local and foreign tourists. In Portland, US, Morey et al. (2002) focused on the preferences of mountain bikers for trails. In Central America, Hearne et al. (2005) determined tourists' preferences toward nature and tourism development. In Finland, Juutinen et al. (2011) analyzed tourists' preferences for biodiversity and recreation in a national park.

The recommendation made by the International Union for Conservation of Nature to reveal the economic value of protected areas for management purpose has become a priority for many park administrations. Making decisions on planning and management without relevant and consistent information about the economic value of the protected areas might lead not only to revenue loses, but also, to inefficient management strategies and to potential irreversible environment damages (Lockwood et al., 2006). On the other hand, more attention is given to the management of protected areas by finding optimal solutions to assure the sustainability of the areas in a world where the increasing trend of demand for outdoor recreation sets pressure on management decisions. The economic values of protected areas assessed using non-market valuation methods offer valuable information for a sustainable management of the area (Bushell et al., 2007).

Previous research points to the importance of knowing and understanding tourists' preferences to support the decisions related to the management of protected areas (Eagles, 2002, Hearne, 2005). The importance of a detailed study referring to 
the monitoring of tourists and revealing their preferences is recognized since a few decades by the International Union for Conservation of Nature as being an "essential element" of developing a management plan (Ceballos-Lascurain, 1996).

The aim of the paper is to investigate how tourists' preferences towards visiting Bucegi Natural Park, Romania, have changed over time. Another objective was to investigate how the choice experiments method was applied in an area with no previous studies.

\section{MATERIALS AND METHODS}

Data were collected through two in-person surveys in 2005 (Study 1) and in 2011 (Study 2), tourists being approached during their visit in Bucegi Natural Park, Romania, which is considered the most popular Romanian park due to the high number of visitors. Its location close to some of the main cities makes it more approachable than other natural/national parks. The marginal willingness to pay was calculated for several characteristics and services of the park and compared over time. During the analyzed period, significant management decisions were taken at the level of the park and many tourism services and facilities have been improved.

The park is described as a set of several attributes with different states that tourists may be willing or not to experience during their visit. Some of the attributes are characteristics of the park and other are facilities/services tourists may want to use or not during the visit. The states of an attribute are known as levels and are presented in Tab. 2 and Tab. 3 along with the estimation results. The choice experiments method was applied to determine the marginal willingness to pay for each attribute included in the choice sets offered to respondents for evaluation (Champ et al., 2003). A choice set is built of three alternatives.

Tab. 1. Choice sets design information for Study 1 and Study 2

\begin{tabular}{|c|c|c|}
\hline Design information & Study 1 & Study 2 \\
\hline Data collection & Summer of 2005 & Summer of 2011 \\
\hline Number of attributes & 9 & 6 \\
\hline $\begin{array}{l}\text { Attributes included in } \\
\text { the choice sets* }\end{array}$ & $\begin{array}{l}\text { 1) one-way distance from home to the park, } \\
\text { in kilometers } \\
\text { (with } 5 \text { levels); } \\
\text { 2) type of landscape } \\
\text { (with } 5 \text { levels); } \\
\text { 3) presence of wilderness } \\
\text { (with } 2 \text { levels); } \\
\text { 4) type of information } \\
\text { (with } 4 \text { levels); } \\
\text { 5) type of infrastructure } \\
\text { (with } 3 \text { levels); } \\
\text { 6) camping } \\
\text { (with } 4 \text { levels); } \\
\text { (with } 3 \text { levels); } \\
\text { 7) level of congestion at campsites } \\
\text { 8) number of phone networks } \\
\text { (with } 3 \text { levels); } \\
\text { 9) fuel price } \\
\text { (with } 3 \text { levels) }\end{array}$ & $\begin{array}{l}\text { one-way distance from home to the par } \\
\text { in kilometers } \\
\text { (with } 4 \text { levels); } \\
\text { 2) nature observation } \\
\text { (with } 2 \text { levels); } \\
\text { 3) type of information } \\
\text { (with } 4 \text { levels); } \\
\text { 4) camping } \\
\text { (with } 3 \text { levels); } \\
\text { (with } 3 \text { levels); } \\
\text { 6) fuel price } \\
\text { (with } 3 \text { levels). }\end{array}$ \\
\hline $\begin{array}{c}\text { Number of choice sets } \\
\text { per respondent }\end{array}$ & ( & 3 \\
\hline Method of distribution & $\begin{array}{l}\text { Randomly, each respondent faced different } \\
\text { choice sets }\end{array}$ & $\begin{array}{c}\text { Randomly, } 8 \text { sets of choice sets were } \\
\text { distributed }\end{array}$ \\
\hline $\begin{array}{l}\text { Number of choice sets } \\
\text { completed }\end{array}$ & 717 & 528 \\
\hline
\end{tabular}


Alternative 1 and Alternative 2, each represent a statement about the park obtained by combining the levels of the attributes, thus the respondents are expected to choose one if they are willing to visit the area. Alternative 3 is considered the status-quo alternative since it represents the choice of not visiting the park as described in the choice set.

The set of attributes were designed to differ over the two studies to capture tourists' satisfaction over time in respond to management changes. The decision to evaluate nine attributes in Study 1 was made because no previous research was found in Romania and the aim was to collect as much information as possible to be able build a broader image. Due to the fact that later some attributes have been proved not being significant for tourism planning (i.e. the number of phone networks), it was decided to reduce the number of attributes, and therefore Study 2 analyzed only six attributes (Tab. 1). In both studies, the fuels price was included to facilitate the estimation of welfare measures.

Data were coded using the effects codes procedure (Louviere et al., 2000, Champ et al., 2003). The alternative specific constant was included in each model to account for the status quo alternative. The multinomial logit model was estimated using the maximum likelihood method (Green, 2003) with the aid of the statistical software Intercooled STATA 10. The marginal willingness to pay (MWTP) is obtained for each attribute level as $\quad\left(-\beta_{\text {effect }} / \beta_{\text {price }}\right)$, where $\beta_{\text {effect }}$ is the coefficient of the attribute level and $\beta_{\text {price }}$ is the coefficient for the fuel price parameter.

\section{RESULTS AND DISCUSSION}

The marginal willingness to pay was calculated for each park attribute using the estimated coefficients of the multinomial logit models (Tab. 2 and Tab. 3). The coefficient of fuel price is negative and statistically significant, meaning that people are willing to pay less if fuel price increases.

As expected, distance does not represent a significant factor of decision for tourists who live closer to the park, perhaps due to the presence of other facilities and services that may influence their visiting decision. In the first study wilderness was highly appreciated $(\mathrm{p}<0.001)$ (Tab. 2). Therefore, tourists were asked in the second study if they would prefer to observe the nature with or without taking guided tours, their choice being the latest ( $\mathrm{p}<0.001$ ) (Tab. 3).

Consulting a list with protected species was not preferred in either study. However, over time, tourists have become more aware about the importance to be informed about the park (recreational activities allowed, camping services offered, marked hiking trails etc.) from an information center $(\mathrm{p}<0.05)(\mathrm{Tab} .3)$. Both studies indicate disagreement for the presence of more than 10 groups at the camping places $(\mathrm{p}<0.05)$. If in the first study tourists have not indicated any significant preference toward the camping places, over the years their behavior seems to have changed towards camping inside the parks, but in organized campsites $(\mathrm{p}<0.05)$. The change in behavior may be the result of the campaigns promoted by the parks' administrations from all over the country on how to be a responsible tourist to recreate in protected areas without harming the nature. The strong preference expressed for the choice of visiting the park and not 'staying at home' remains over the years $(\mathrm{p}<0.001)$, an important result that sustains the need to find optimal solutions for practicing tourism in the park.

The statistically significant attributes were further analyzed in comparison between the two studies (Fig. 1). The preferences expressed by tourists toward these attributes represent decision factors on whether to visit Bucegi Natural Park in future or not. The need of an information center, the need of organized campsites inside the park, the crowded camping places are all deeper emphasized in 2011 than in 2005 as important issues to be solved, clearly showing that people are more aware of their needs when recreating in a natural park. This behavior is also the result of many actions taken in the last years at national, regional and local level to inform and even educate people on how to be responsible when recreating in protected areas.

Changes occurred in the meantime within the project "Optimizing the management of visitors by improving the visiting infrastructure" implemented in Bucegi Natural Park during the period 2011-2014, some of the outcomes being the visitor center in Busteni, the information point in Moroieni and the seven thematic trails. In Bucegi Natural Park, first attention was given to the brown bear species, and only recently 
to tourism, the first being considered a critical issue for the region. However, not all changes in behavior are as expected. Tourists expressed their preferences to capture the motions of wildlife by themselves without being guided. This behavior can be changed if proper management actions

Tab. 2. Estimation results - Study 1

\begin{tabular}{|c|c|c|c|c|c|}
\hline Attributes & Levels & Coefficients & $\begin{array}{l}\text { Standard } \\
\text { error }\end{array}$ & $P$ value & $\begin{array}{l}\text { MWTP } \\
\text { (RON) }\end{array}$ \\
\hline \multirow{5}{*}{$\begin{array}{l}\text { One-way } \\
\text { distance from } \\
\text { home to the } \\
\text { park }(\mathrm{km})\end{array}$} & $<1$ hour $^{\mathrm{BL}}$ & -0.2300 & & & -1.51 \\
\hline & 1-2 hours & 0.0891 & 0.1127 & 0.429 & 0.58 \\
\hline & 2-4 hours & $0.2741^{* *}$ & 0.1117 & 0.014 & 1.79 \\
\hline & 4-6 hours & 0.1723 & 0.1109 & 0.120 & 1.13 \\
\hline & $>6$ hours & $-0.3055^{* * *}$ & 0.1144 & 0.008 & -2.00 \\
\hline \multirow{5}{*}{ Landscape } & $\begin{array}{l}\text { Impressive karst relief (pass, gorge, crest, unique } \\
\text { forms) }\end{array}$ & 0.6266 & & & 4.10 \\
\hline & Glacier lakes & -0.1203 & 0.1117 & 0.282 & -0.79 \\
\hline & $\begin{array}{c}\text { Hill area with archeological vestiges and/or cultural } \\
\text { monuments }\end{array}$ & $-0.4683^{* * *}$ & 0.1151 & 0.000 & -3.06 \\
\hline & Waterside, riverside & $-0.5301^{* * *}$ & 0.1140 & 0.000 & -3.47 \\
\hline & Steep slopes with rocks, forested & $0.4921^{* * *}$ & 0.1110 & 0.000 & 3.22 \\
\hline \multirow{2}{*}{ Wilderness } & Yes & $0.5002^{* * *}$ & 0.1118 & 0.000 & 3.27 \\
\hline & $\mathrm{No}^{\mathrm{BL}}$ & -0.5002 & & & -3.27 \\
\hline \multirow{4}{*}{ Information } & Guidebook and frequent hiking marks & 0.1256 & 0.0992 & 0.206 & 0.82 \\
\hline & Guidebook and information center & -0.0636 & 0.0967 & 0.511 & -0.42 \\
\hline & Only guidebook with map ${ }^{\mathrm{BL}}$ & 0.1206 & & & 0.79 \\
\hline & $\begin{array}{c}\text { Guidebook, information center and the protected } \\
\text { species list }\end{array}$ & $-0.1826^{*}$ & 0.0966 & 0.059 & -1.20 \\
\hline \multirow{4}{*}{ Infrastructure } & Parking and camping place & 0.0275 & 0.0958 & 0.774 & 0.18 \\
\hline & Only parking ${ }^{\mathrm{BL}}$ & -0.1898 & & & -1.24 \\
\hline & Parking and hotel & $-0.1875^{*}$ & 0.0994 & 0.059 & -1.23 \\
\hline & $\begin{array}{l}\text { Parking and camping with facilities (water, WC, } \\
\text { shower) }\end{array}$ & $0.3498^{* * *}$ & 0.0965 & 0.000 & 2.29 \\
\hline \multirow{3}{*}{ Camping } & Inside the forests & -0.0157 & 0.0800 & 0.844 & -0.10 \\
\hline & $\begin{array}{l}\text { As near as possible to access road, fenced places, } \\
\text { guarded }\end{array}$ & 0.0368 & 0.0801 & 0.646 & 0.24 \\
\hline & Should not be allowed in park ${ }^{\mathrm{BL}}$ & -0.0211 & & & -0.14 \\
\hline \multirow[t]{3}{*}{ Congestion } & $1-5$ groups $^{\mathrm{BL}}$ & 0.1025 & & & 0.67 \\
\hline & 5-10 groups & 0.0798 & 0.0797 & 0.316 & 0.52 \\
\hline & $>10$ groups & $-0.1823^{* *}$ & 0.0802 & 0.023 & -1.19 \\
\hline \multirow[t]{3}{*}{ Phone network } & 1 network ${ }^{\mathrm{BL}}$ & 0.0073 & & & 0.05 \\
\hline & 2 networks & -0.0634 & 0.0790 & 0.422 & -0.41 \\
\hline & 3 networks & 0.0561 & 0.0795 & 0.481 & 0.37 \\
\hline \multirow[t]{3}{*}{ Fuel price } & & $-0.1528^{* * *}$ & 0.0237 & 0.000 & \\
\hline & Alternative specific constant & $-1,4441^{* * *}$ & 0.1396 & 0.000 & \\
\hline & $\begin{array}{c}\operatorname{Ln}(\mathrm{L}) \\
\text { Pseudo-R2 } \\
\text { Number of observations }\end{array}$ & $\begin{array}{l}-1181.0531 \\
0.2079 \\
2151\end{array}$ & & & \\
\hline L & Idard errors in parentheses; Significan & $\frac{2151}{,{ }^{*}=10 \%}$ & & & \\
\hline
\end{tabular}


Tab. 3. Estimation results - Study 2

\begin{tabular}{|c|c|c|c|c|c|}
\hline Attributes & Levels & Coefficients & $\begin{array}{l}\text { Standard } \\
\text { error }\end{array}$ & $P$ value & $\begin{array}{l}\text { MWTP } \\
(\mathrm{RON})\end{array}$ \\
\hline \multirow{4}{*}{$\begin{array}{l}\text { One-way } \\
\text { distance from } \\
\text { home to the } \\
\text { park }(\mathrm{km})\end{array}$} & $<150 \mathrm{~km}^{\mathrm{BL}}$ & -0.1933 & & & -7.89 \\
\hline & $150-300 \mathrm{~km}$ & -0.0653 & 0.1161 & 0.575 & -2.67 \\
\hline & $301-450 \mathrm{~km}$ & $0.3142^{* * *}$ & 0.1267 & 0.013 & 12.82 \\
\hline & $>450 \mathrm{~km}$ & -0.0556 & 0.1310 & 0.670 & -2.27 \\
\hline \multirow{2}{*}{$\begin{array}{c}\text { Nature } \\
\text { observation }\end{array}$} & Without guide ${ }^{\text {BL }}$ & 0.2763 & & & 11.28 \\
\hline & With guide & $-0.2763^{* * *}$ & 0.0698 & 0.000 & -11.28 \\
\hline \multirow{4}{*}{$\begin{array}{l}\text { Type of } \\
\text { information }\end{array}$} & Marks ${ }^{\mathrm{BL}}$ & -0.3999 & & & -16.32 \\
\hline & Marks and information center & $0.2945^{* *}$ & 0.1367 & 0.031 & 12.02 \\
\hline & Marks and map & 0.1418 & 0.1245 & 0.255 & 5.79 \\
\hline & $\begin{array}{l}\text { Marks and information center and list with protected } \\
\text { species }\end{array}$ & -0.0364 & 0.1417 & 0.798 & -1.49 \\
\hline \multirow{3}{*}{ Camping } & $\begin{array}{l}\text { Not inside the parks } \\
{ }^{\mathrm{BL}} \\
\end{array}$ & -0.2633 & & & -10.75 \\
\hline & Inside the parks, in unorganized campsites & 0.0568 & 0.0962 & 0.554 & 2.32 \\
\hline & Inside the parks, in organized campsites & $0.2065^{* *}$ & 0.1041 & 0.047 & 8.43 \\
\hline \multirow{3}{*}{$\begin{array}{l}\text { Number of } \\
\text { groups at } \\
\text { campsites }\end{array}$} & $1-5$ groups $^{\mathrm{BL}}$ & 0.5397 & & & 22.03 \\
\hline & 5-10 groups & 0.0213 & 0.0959 & 0.824 & 0.87 \\
\hline & $>10$ groups & $-0.5610^{* * *}$ & 0.1283 & 0.000 & -22.90 \\
\hline \multirow[t]{2}{*}{ Fuel price } & & $-0.0245^{* *}$ & 0.0135 & 0.050 & \\
\hline & Alternative specific constant & $-2.9610^{* *}$ & 0.1880 & 0.000 & \\
\hline & $\begin{array}{c}\text { Ln(L) } \\
\text { Pseudo-R2 } \\
\text { Number of observations }\end{array}$ & $\begin{array}{c}-800.4308 \\
0.2710 \\
1584\end{array}$ & & & \\
\hline sas I & $\begin{array}{l}\text { Number of observations } \\
\text { andard errors in parentheses; Significance levels: }{ }^{* * *}=1 \%,{ }^{* *}= \\
\text { EUR0 }=4.2379 \text { RON }\end{array}$ & $\frac{1584}{\%,{ }^{*}=10 \% ;}$ & & & \\
\hline
\end{tabular}

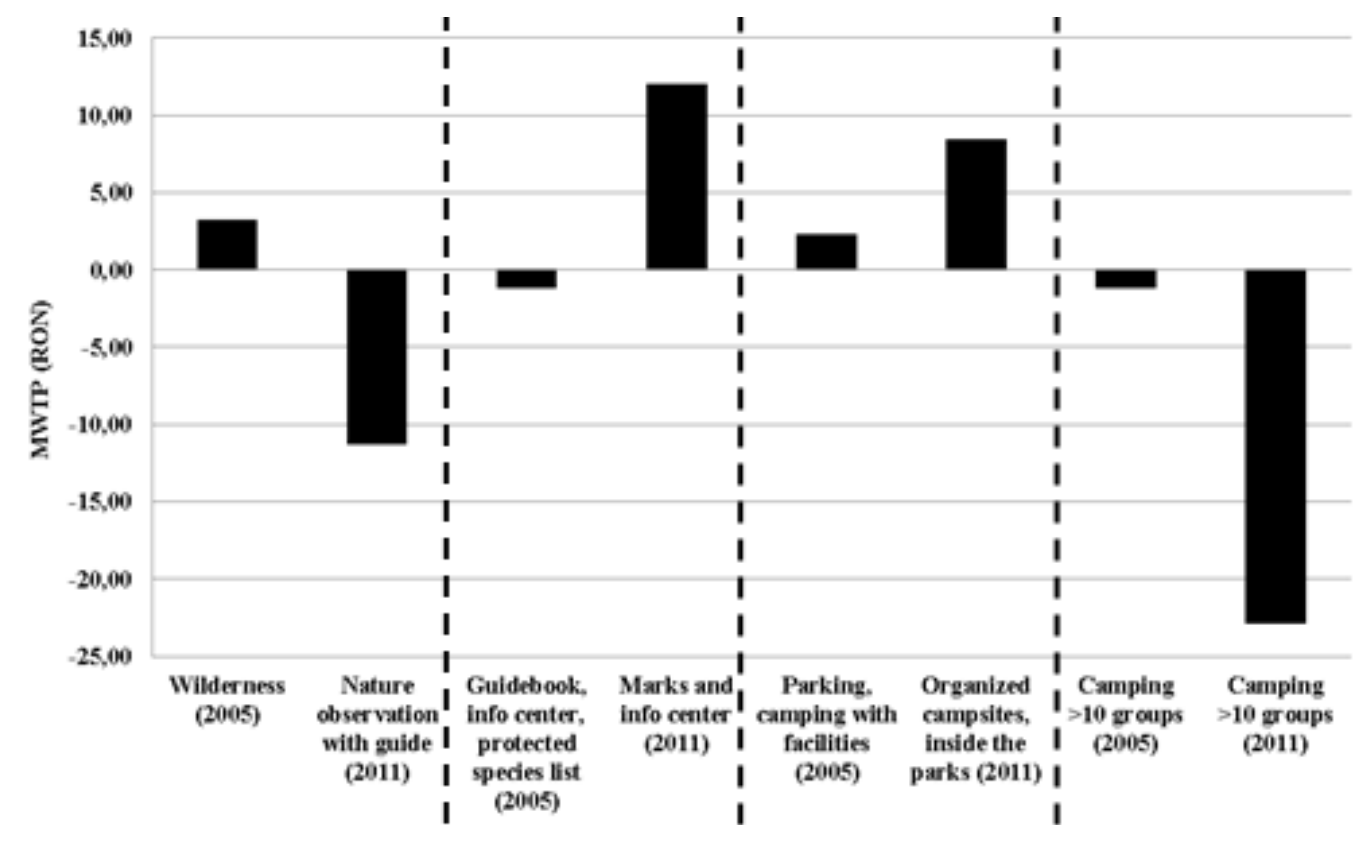

Fig. 1. Analysis of marginal WTP for park attributes over the studied years 
are taken, for instance presenting the advantages of being aware of what to observe and how to observe may increase the interest of tourists for this park service, with benefits on both sides.

\section{CONCLUSION}

The changes in tourists' behavior may be the result of some actions that occurred in the last years either in Bucegi Natural Park or at national level. Several projects were conducted in many Romanian protected areas, mainly on environmental protection, which has a significant contribution on educating tourists and making them aware of the importance of preserving the nature as it is for future 'own-use' and future generations.

The trend of changes in tourists' behavior and perception revealed from these two studies offers more reliable information on which efficient decisions can be taken at the park administration level. The changes in behavior indicate that over the years people became more conscious of the importance of sustainability of the natural park and also that the park administration has taken actions towards an optimal recreation use of the park.

When using the choice experiments method on a subject or area where no previous or similar studies exist, it is recommended to do a follow up study to find the best attributes and their optimal number to be analyzed in the field. In this particular case, Study 1 may be considered as a starting point for applying the choice experiments method to evaluate a Romanian protected area; it helped in optimizing the number of attributes and revealing valuable information for management decision elicited directly from the 'customer' who 'uses' the park: the tourist who visited and performed recreational activities inside the park.

The existing park management plan can be improved by considering as decision factors the estimated values obtained in these studies, which show the marginal willingness to pay of tourists for several park characteristics and/or services. The magnitude of the welfare measures reveal not only their preferences and needs, but also their level of understanding and knowledge as regard to the importance of preserving nature and being a responsible tourist. Thus, this information sustains the need of funds to develop tourism opportunities and services in a sustainable manner.

Acknowledgments. Financial support for this work was provided by CNCSIS-UEFISCSU, Romania, project number PNII-RU type PD code $271 / 2010$.

\section{REFERENCES}

1. Bushell R, Eagles PA (2007). Benefits beyond Boundaries: Tourism and Protected Areas. CABI Press, Oxfordshire \& Cambridge.

2. Ceballos-Lascurain, H. (1996). Tourism, Ecotourism and Protected Areas. IUCN, Gland, Switzerland and Cambridge, UK.

3. Champ PA, Boyle KJ, Brown TC (2003). A Primer on Nonmarket Valuation. Kluwer. Academic Publishers. Netherlands.

4. Eagles PFJ, McCool ST (2002). Tourism in national parks and protected areas: planning and management. CABI Publishing

5. Greene WH (2003). Econometric Analysis. 5th Edition. New Jersey: Prentice Hall.

6. Hearne RR, Salinas ZM (2002). The Use of Choice Experiments in the Analysis of Tourist Preferences for Ecotourism Development in Costa Rica. Journal of Environmental Management. 65:153-163.

7. Hearne RR, Santos CA (2005). Tourists' and Locals' Preferences toward Ecotourism Development in the Maya Biosphere Reserve, Guatemala. Environmental, Development and Sustainability. 7:303-318.

8. Juutinen A, Mitani Y, Mantymaa E, Shoji Y, Siikamaki P, Svento R (2011). Combining Ecological and Recreational Aspects in National Park Management: A Choice Experiment Application. Ecological Economics. 70:12311239.

9. Lockwood M, Worboys G, Kothari A (2006). Managing Protected Areas: A Global Guide. Earthscan. London.

10. Louviere JJ, Hensher DA, Swait JD (2000). Stated Choice Methods - Analysis and Application. Cambridge University Press.

11. Morey ER, Buchanan T, Waldman DM (2002). Estimating the Benefits and Costs to Mountain Bikers of Changes in Trail Characteristics, Access Fees, and Site Closures: Choice Experiments and Benefits Transfer. Journal of Environmental Management. 64: 411-422. 